\title{
Total phenolic, total flavonoid contents, and in vitro biological activities of Cephalaria procera Fisch. \& Ave-Lall.
}

\author{
Nurdan Yazıcı Bektaș’ (D), Burak Barut² (D), Emel Mataracı Kara ${ }^{3}$ (D) Yeter Yeșil Cantürk ${ }^{4}$ (D) \\ ${ }^{1}$ Karadeniz Technical University, Faculty of Pharmacy, Department of Pharmacognosy, Trabzon, Turkey \\ ${ }^{2}$ Karadeniz Technical University, Faculty of Pharmacy, Department of Biochemistry, Trabzon, Turkey \\ ${ }^{3}$ Isstanbul University, Faculty of Pharmacy, Department of Pharmaceutical Microbiology, İstanbul, Turkey \\ 4Istanbul University, Faculty of Pharmacy, Department of Pharmaceutical Botany, İstanbul, Turkey
}

ORCID IDs of the authors: N.Y.B. 0000-0001-7617-1701; B.B. 0000-0002-7441-8771; E.M.K. 0000-0003-4541-1893;

Y.Y.C. 0000-0002-4458-7881

Cite this article as: Yazici Bektas, N., Barut, B., Mataraci Kara, E., \& Yesil Canturk, Y. (2021). Total phenolic, total flavonoid contents, and in vitro biological activities of Cephalaria procera Fisch. \& Ave-Lall. İstanbul Journal of Pharmacy, 51 (3), 365-371.

\begin{abstract}
Background and Aims: This study aims to determine total phenolic, total flavonoid contents and in vitro biological activities of methanol (CEP-1), n-butanol (CEP-2), water (CEP-3), n-hexane (CEP-4) extracts obtained from Cephalaria procera.

Methods: The total phenolic and flavonoid content analysis, in vitro DPPH radical scavenging activities, cholinesterase, and tyrosinase inhibitory properties of the extracts were evaluated using spectrophotometric assays. DNA-damage and DNAdamage protective effects of the extracts were examined using agarose gel electrophoresis method. Antimicrobial activities of the extracts were determined by microdilution method.

Results: CEP-3 had the best total phenolic content (79.64 $1.11 \mathrm{mg} \mathrm{GAE} / \mathrm{g}$ dry weight), and CEP-1 had the highest total flavonoid content ( $15.33 \pm 0.27 \mathrm{mg} Q E E / g$ dry weight) among tested extracts. CEP- 1 showed the highest radical scavenging activity with $83.21 \pm 3.20 \mu \mathrm{g} / \mathrm{mL}$ of IC ${ }_{50}$ value. CEP-3 exerted the highest AChE and BuChE inhibitory action with $134.63 \pm 4.49 \mu \mathrm{g} / \mathrm{mL}$ and $62.76 \pm 0.63 \mu \mathrm{g} / \mathrm{mL}$ of IC 50 values, respectively. CEP-3 showed significant tyrosinase inhibitory action with $51.95 \pm 0.35 \mu \mathrm{g} / \mathrm{mL}$ $I_{50}$ value compared to kojic acid $(58.26 \pm 0.25 \mu \mathrm{g} / \mathrm{mL})$. CEP- 1 and CEP-3 were tested, and the both extracts did not damage supercoiled DNA at studied concentrations. Incidentally, results indicated that CEP-1 and CEP-3 protected supercoiled DNA against Fenton's reagents. CEP-4 exhibited the highest antimicrobial activity on C. tropicalis with the MIC value of $156.2 \mu \mathrm{g} / \mathrm{mL}$. Conclusion: The results showed that crude and subextracts of $C$. procera exerted several moderate activities on tested systems. It suggested that the species might be a promising medicinal plant for the treatment or prevention of several diseases associated with skin damage and wounds.
\end{abstract}

Keywords: Antioxidant, antimicrobial, anticholinesterase, Cephalaria procera, DNA protective, tyrosinase

\section{INTRODUCTION}

Natural products are used extensively in drug research, and it is known that many active substances of herbal origin are used use today in modern pharmacotherapy directly or indirectly. According to the World Health Organization, approximately 20.000 plants are still used for treatment today, and approximately $80 \%$ of the world population primarily resorts to herbal drugs to eliminate their health problems. In addition, 1881 compounds of natural origin have been approved by the FDA for medical use since 1981, and 25\% of pharmaceutical preparations contain active ingredients of plant origin (Faydaoğlu \& Sürücüoğlu, 2011; Newman \& Cragg, 2020).

The genus Cephalaria Schrad. ex Roem. \& Schult. is a member of the Caprifoliaceae family. South Africa and the Holarctic Kingdom (from Balkans to West China and from South Ukraine to Middle East) are the main centers of distribution of the genus. It has been

Address for Correspondence:

Nurdan Yazıcı BEKTAȘ, e-mail: nurdanyazici@ktu.edu.tr, ecz.nurdanyazici@gmail.com

This work is licensed under a Creative Commons Attribution 4.0 International License.
Submitted: 01.10 .2021

Revision Requested: 10.10 .2021

Last Revision Received: 25.10 .2021

Accepted: 01.11.2021

Published Online: 04.11.2021 
determined that 94 species are grown in the world and 39 species in Turkey (Göktürk and Sümbül, 2014). Fresh stems of Cephalaria procera Fisch. \& Avé-Lall. are used for wound healing and as antihemorrhagic, traditionally. The species is called as Ganteper, Gulinga, Cevrük and Cipreş in Turkey (Özgen, Kaya, \& Houghton, 2012; Kahraman et al., 2019).

It has been reported that Cephalaria is a rich genus in terms of saponins (Boke Sarikahya, Goren, Sumer Okkali, \& Kirmizigul, 2021), phenolic compounds (Chrzaszcz, Krzeminska, Celinski, \& Szewczyk, 2021), flavonoids (Godjevac et al., 2004), lignans (Pasi, Aligiannis, Skaltsounis, \& Chinou, 2002), triterpene glycosides (Top, Sarikahya, Nalbantsoy, \& Kirmizigul, 2017; Böke Sarıkahya \& Kirmizigul, 2010), iridoid glycosides (Mustafaeva et al., 2011) as phytochemicals. Studies about biological activities showed that Cephalaria species have antioxidant (Böke Sarıkahya, Pekmez, Arda, Kayce, Karabay Yavaşoğlu, \& Kirmizigul, 2011; Godjevac et al., 2004), antimicrobial (Böke Sarıkahya, Pekmez, Arda, Kayce, Karabay Yavaşoğlu, \& Kirmizigul, 2011, Böke Sarıkahya, \& Kirmizigul S, 2010), hemolytic (Top, Sarikahya, Nalbantsoy, \& Kirmizigul, 2017), immunomodulatory (Celenk, Boke Sarikahya, \& Kirmizigul, 2020; Top, Sarikahya, Nalbantsoy, \& Kirmizigul, 2017), and cytotoxic activities (Celenk, Boke Sarikahya, \& Kirmizigul, 2020; Pasi, Aligiannis, Skaltsounis, \& Chinou, 2002).

In this study, it was aimed to test total phenolic, total flavonoid contents and investigate in vitro biological activities of Cephalaria procera extracts. To the best of our knowledge, there has not been any study conducted to investigate the cholinesterase and tyrosinase inhibitory activities, antimicrobial activity on yeasts, and supercoiled DNA damage and damage protective effects of Cephalaria procera.

\section{MATERIALS AND METHODS}

\section{Plant material}

The aerial parts of Cephalaria procera were collected from Erzurum (Eastern Turkey) by Dr. Yeter Yeşil, Nurdan Yazıcı Bektaş and Burak Bektaş in July 2017. Voucher specimens were authenticated by Dr. Yeter Yeşil. These specimens were deposited at the Herbarium of İstanbul University (ISTE 115 326, ISTE 115 327).

\section{Extraction}

Air dried and powdered aerial parts of Cephalaria procera were extracted at room temperature with methanol for overnight three times. The methanol extract was concentrated to dryness under reduced pressure. The crude methanol extract (CP1) dissolved with distilled water and extracted with n-butanol using partition method. By this way water extract (CP-3) was obtained. Then the $n$-butanol phase was concentrated and extracted with $n$-hexane. Finally, $n$-butanol (CP-2) and n-hexane (CP-4) were obtained, concentrated to dryness, and stored at refrigerator (Top, Sarikahya, Nalbantsoy, \& Kirmizigul, 2017).

\section{Total phenolic content analysis}

The total phenolic content analyses of the extracts were evaluated utilizing the Folin-Ciocalteu colorimetric assay according to study of Barut \& Şöhretoğlu (Barut \& Şöhretoğlu, 2020). The results were expressed as mg gallic acid equivalent (GAE) per $g$ of dry weight of the extracts.

\section{Total flavonoid content analysis}

The total flavonoid content analyses of the extracts were evaluated aluminium nitrate colorimetric assay (Barut et al., 2017). The results were expressed as mg quercetin equivalent (QEE) per $\mathrm{g}$ of dry weight of the extracts. The extracts, 10\% aluminium nitrate and $1 \mathrm{M}$ ammonium acetate were added to a tube. The mixtures were incubated for $40 \mathrm{~min}$ at room temperature. Afterwards, the absorbance was measured at $415 \mathrm{~nm}$.

\section{In vitro Biological activities}

\section{DPPH radical scavenging effects of the extracts}

The DPPH (2,2-Diphenyl-1-picrylhydrazyl) radical scavenging effects of the extracts were determined using spectrophotometric assay according to previous study conducted by (Barut \& Şöhretoğlu, 2020). The results were expressed as $I C_{50}$ (Halfmaximal inhibitory concentration) values. Gallic acid (GA) was used as a positive control.

\section{AChE/BuChE inhibitory effects of the extracts}

The acetylcholinesterase (AChE) and buthyrylcholinesterase (BuChE) inhibitory effects of the extracts were evaluated using the previously reported method (Barut \& Şöhretoğlu, 2020). The results were expressed as $I C_{50}$ values. Galantamine was used as a positive control.

\section{Tyrosinase inhibitory effects of the extracts}

The tyrosinase (Tyr) (Sigma, T3824) inhibitory effects of the extracts were evaluated using previous reported method (Barut \& Şöhretoğlu, 2020). The results were expressed as $I C_{50}$ values. Kojic acid was used as a positive control.

\section{DNA damage effects of CEP-1 and CEP-3}

The supercoiled pBR322 plasmid DNA damage effects of CEP-1 and CEP-3 was determined using agarose gel electrophoresis according to the previous study (Şöhretoğlu, Barut, Sari, Özel, \& Arroo, 2020). In this study, Tris- $\mathrm{HCl}(50 \mathrm{mM}, \mathrm{pH}$ 7), plasmid DNA, extracts at various concentrations $(50,100$, and $200 \mu \mathrm{g} /$ $\mathrm{mL}$ ) was mixed at $37^{\circ} \mathrm{C}$ for $1 \mathrm{~h}$. Afterwards, loading buffer (bromophenol blue, sodium dodecyl sulphate, xylene cyanol, glycerol) was added and the mixtures were loaded on gel $(0.8 \%$ $(\mathrm{m} / \mathrm{v})$ ) with ethidium bromide staining for $90 \mathrm{~min}$ at $100 \mathrm{~V}$ in Tris-acetic acid-EDTA (TAE) buffer. After electrophoresis, gel was visualized and calculated using BioRad Gel Doc XR system and Image Lab Version 5.0.1 software.

\section{DNA damage protective effects of CEP-1 and CEP-3 on Fenton reagents}

The supercoiled pBR322 plasmid DNA damage protective actions of CEP-1 and CEP-3 on Fenton's reagents were evaluated using agarose gel electrophoresis (Şöhretoğlu, Barut, Sari, Özel, \& Arroo, 2020). In this study, Tris- $\mathrm{HCl}(50 \mathrm{mM}, \mathrm{pH} 7)$, plasmid DNA, $\mathrm{H}_{2} \mathrm{O}_{2}(2 \%), \mathrm{FeSO}_{4}(1 \mathrm{mM})$, extracts at various concentrations $(50,100$, and $200 \mu \mathrm{g} / \mathrm{mL})$ was mixed at $37^{\circ} \mathrm{C}$ for $1 \mathrm{~h}$. The electrophoresis studies were performed according to the above method. 
Yazıcı Bektaş et al. Total phenolic, total flavonoid contents, and in vitro biological activities of Cephalaria procera Fisch. \& Ave-Lall.

\section{Antimicrobial effects of the extracts}

The antimicrobial activities of CEP-1, CEP-2, and CEP-3 extracts were determined against a set of microorganisms including Staphylococcus aureus ATCC 29213, Staphylococcus epidermidis ATCC 12228, Enterococcus faecalis ATCC 29212, Escherichia coli ATCC 25922, Klebsiella pneumoniae ATCC 4352, Pseudomonas aeruginosa ATCC 27853, Proteus mirabilis ATCC 14153, Candida albicans ATCC 10231, Candida parapsilosis ATCC 22019, and Candida tropicalis ATCC 750 using the broth microdilution technique approved by Clinical Laboratory Standards Institute (CLSI) (CLSI, 1997, 2020)

Cefuroxime, cefuroxime-Na, amikacin, ceftazidime and fluconazole were used as positive control; RPMI-1640 medium for the yeast strain and Mueller-Hinton broth for bacteria were used as negative control.

\section{Statistical analysis}

The results were expressed as the mean \pm SD and were analysed using GraphPad Prism 5.0. In this work, two-way analysis of variance (ANOVA) followed by Bonferroni tests were used as statistical analysis.

\section{RESULTS}

Total phenolic and total flavonoid contents of the extracts In this work, total phenolic and total flavonoid contents of the extracts were investigated and the results were given in
Table 1. CEP-3 had the highest total phenolic content with $79.64 \pm 1.11 \mathrm{mg} \mathrm{GAE} / \mathrm{g}$ dry weight among tested extracts. Also, the total phenolic contents of the extracts (CEP-1, CEP-2, and (EP-4) were 68.81 $\pm 4.11,13.38 \pm 0.82$, and 50.05 $\pm 5.14 \mathrm{mg} \mathrm{GAE} / \mathrm{g}$ dry weight, respectively. On the other hand, the total flavonoid contents of CEP-1, CEP-2, CEP-3, and CEP-4 were calculated as $15.33 \pm 0.27 \mathrm{mg}$ QEE/g dry weight, 2.14 $\pm 0.50 \mathrm{mg}$ QEE/g dry weight, $11.27 \pm 2.21 \mathrm{mg}$ QEE/g dry weight, and $5.25 \pm 0.88 \mathrm{mg}$ QEE/g dry weight, respectively.

\section{DPPH radical scavenging effects of the extracts}

In this study, DPPH radical scavenging effects of the extracts were determined using a spectrophotometric method. The results were presented in Table 1. CEP-1 showed the highest radical scavenging effect with $83.21 \pm 3.20 \mu \mathrm{g} / \mathrm{mL}$ of $\mathrm{IC}_{50}$ value among the tested extracts as shown in Table 1. However, CEP1 found to have less scavenging properties than gallic acid (GA) $\left(\mathrm{IC}_{50}=68.25 \pm 0.35 \mu \mathrm{g} / \mathrm{mL}\right)$ which used as a positive control. In addition, the $\mathrm{IC}_{50}$ values of CEP-2, CEP-3, and CEP-4 were determined as $264.05 \pm 6.52 \mu \mathrm{g} / \mathrm{mL}, 89.91 \pm 0.13 \mu \mathrm{g} / \mathrm{mL}$, and $179.02 \pm 0.23 \mu \mathrm{g} / \mathrm{mL}$, respectively.

\section{AChE and BuChE inhibitory effects of the extracts}

In this paper, the AChE obtained from Electrophorus electricus (electric eel) and BuChE from equine serum inhibitory properties of the extracts were investigated, and the results were shown in Table 2. The $\mathrm{IC}_{50}$ value of CEP-3 was $134.63 \pm 4.49 \mu \mathrm{g} /$ $\mathrm{mL}$ on $\mathrm{AChE}$, as shown in Table 2. Other extracts have $\mathrm{IC}_{50}$

Table 1. Total phenolic and flavonoid content, and DPPH radical scavenging effects of $C$. procera extracts.

\begin{tabular}{|c|c|c|c|}
\hline Extracts & $\begin{array}{l}\text { Total phenolic content } \\
\text { (mg GAE/g extract) }\end{array}$ & $\begin{array}{l}\text { Total flavonoid content } \\
\text { (mg QEE/g extract) }\end{array}$ & $\begin{array}{c}\text { DPPH } \\
\left(\mu \mathrm{g} / \mathrm{mL}_{1}, \mathrm{IC}_{50}\right)\end{array}$ \\
\hline CEP-1 & $68.81 \pm 4.11$ & $15.33 \pm 0.27$ & $83.21 \pm 3.20$ \\
\hline CEP-2 & $13.38 \pm 0.82$ & $2.14 \pm 0.50$ & $264.05 \pm 6.52$ \\
\hline CEP-3 & $79.64 \pm 1.11$ & $11.27 \pm 2.21$ & $89.91 \pm 0.13$ \\
\hline CEP-4 & $50.05 \pm 5.14$ & $5.25 \pm 0.88$ & $179.02 \pm 0.23$ \\
\hline GA & - & - & $68.25 \pm 0.35$ \\
\hline
\end{tabular}

Table 2. AChE, BuChE, and Tyr inhibitory effects of $C$. procera extracts.

\begin{tabular}{|c|c|c|c|}
\hline Extracts & $\begin{array}{c}\text { AChE } \\
\left(\mu \mathrm{g} / \mathrm{mL}, \mathrm{IC}_{50}\right)\end{array}$ & $\begin{array}{c}\text { BuChE } \\
\left(\mu \mathrm{g} / \mathrm{mL}, \mathrm{IC}_{50}\right)\end{array}$ & $\begin{array}{c}\text { Tyr } \\
\left(\mu \mathrm{g} / \mathrm{mL}, \mathrm{IC}_{50}\right)\end{array}$ \\
\hline CEP-1 & $>200$ & $73.16 \pm 1.94$ & $56.13 \pm 1.17^{\mathrm{ns}}$ \\
\hline CEP-2 & $>200$ & $87.07 \pm 1.88$ & $100.19 \pm 2.00$ \\
\hline CEP-3 & $134.63 \pm 4.49$ & $62.76 \pm 0.63$ & $51.95 \pm 0.35^{* *}$ \\
\hline CEP-4 & $>200$ & $78.32 \pm 3.58$ & $63.55 \pm 2.75$ \\
\hline Galantamine & $20.30 \pm 0.25$ & $36.05 \pm 0.18$ & - \\
\hline Kojic acid & - & - & $58.26 \pm 0.25$ \\
\hline \multicolumn{4}{|c|}{$\begin{array}{l}\text { AChE: Acetylcholinesterase, BuChE: Buthyrylcholinesterase, Tyr: Tyrosinase, CEP-1: Methanol extract of } C \text {. procera, CEP-2: } N \text { - butanol extract } \\
\text { of } C \text {. procera, CEP-3: Water extract of } C \text {. procera, CEP- } 4 \text { : } N \text {-hexane extract of } C \text {. procera } \\
\text { *Values expressed are means } \pm \text { standard deviation of three parallel measurements, }{ }^{* *} p<0.001 \\
\text { ns: not significant vs positive control. }\end{array}$} \\
\hline
\end{tabular}


values higher than $200 \mu \mathrm{g} / \mathrm{mL}$. On the other hand, CEP-3 had the highest BuChE inhibition with $62.76 \pm 0.63 \mu \mathrm{g} / \mathrm{mL}$ of $\mathrm{IC}_{50}$ value followed by CEP-1 with $73.16 \pm 1.94 \mu \mathrm{g} / \mathrm{mL}$. However, galantamine $\left(\mathrm{IC}_{50}=20.30 \pm 0.25\right.$ for $\mathrm{AChE}, 36.05 \pm 0.18$ for BuChE $)$ which was used as a positive control, had higher inhibition than CEP-3 on AChE and BuChE.

\section{Tyrosinase inhibitory effects of the extracts}

In this study, the in vitro tyrosinase inhibitory properties of the extracts were determined using a spectrophotometric assay. The results were tabulated in Table 2 . The $I_{50}$ value of CEP-3 was $51.95 \pm 0.35 \mu \mathrm{g} / \mathrm{mL}$ on Tyr. CEP-3 showed significant inhibitory action when compared to kojic acid $(58.26 \pm 0.25 \mu \mathrm{g} / \mathrm{mL})$ against Tyr $(p<0.001)$. CEP-1 had similar inhibitory effect with kojic acid according to the their $I C_{50}$ values.

\section{Supercoiled DNA damage effects of CEP-1 and CEP-3}

Supercoiled pBR322 plasmid DNA damage effects of CEP-1 and CEP-3 which were the most potent radical scavenging extracts, were evaluated using agarose gel electrophoresis. The results were given in Figure 1. It is well-known that plasmid DNA has three forms on gel: form I (supercoiled form moves the fastest); form II (nicked form); form III (linear form moves the slowest). As shown in Figure 1 (lane 1), the percentage of form I was about 75\%. At increasing concentrations CEP-1 and CEP-3, the amounts of form I did not change significantly, and they were determined as about $70-75 \%$. These results showed that both extracts did not show any damage effects on supercoiled pBR322 plasmid DNA at studied concentrations.

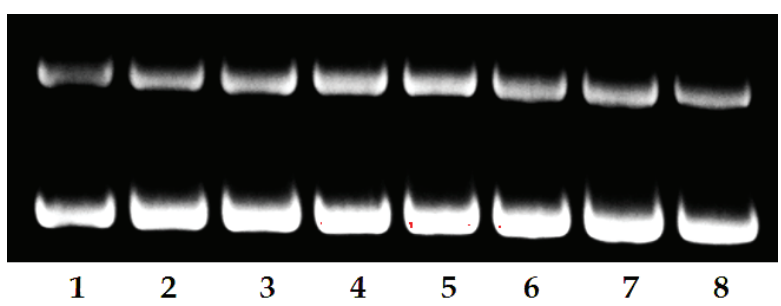

Figure 1. DNA damage effects of the extracts. Lane 1: DNA control; lane 2-4: DNA+ (50, 100, and $200 \mu \mathrm{g} / \mathrm{mL}$ of CEP-1); lane 5-7: DNA+ (50, 100 , and $200 \mu \mathrm{g} / \mathrm{mL}$ of (EP-3).

\section{Supercoiled DNA damage protective effects of CEP-1} and CEP-3 on Fenton's reagents

Supercoiled pBR322 plasmid DNA damage protective effects of CEP-1 and CEP-3 against Fenton's reagents were investigat-

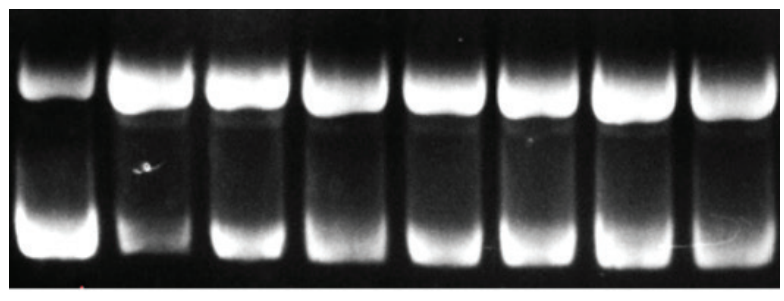

$$
\begin{array}{llllllll}
1 & 2 & 3 & 4 & 5 & 6 & 7 & 8
\end{array}
$$

Figure 2. DNA damage protecitve effects of the extracts against Fenton reagents. Lane 1: DNA control; lane 2: DNA+FeSO ${ }_{4}+\mathrm{H}_{2} \mathrm{O}_{2}$; lane 3-5: DNA+FeSO ${ }_{4}+\mathrm{H}_{2} \mathrm{O}_{2}+(50,100$, and $200 \mu \mathrm{g} / \mathrm{mL}$ of CEP-1); lane 6-8:

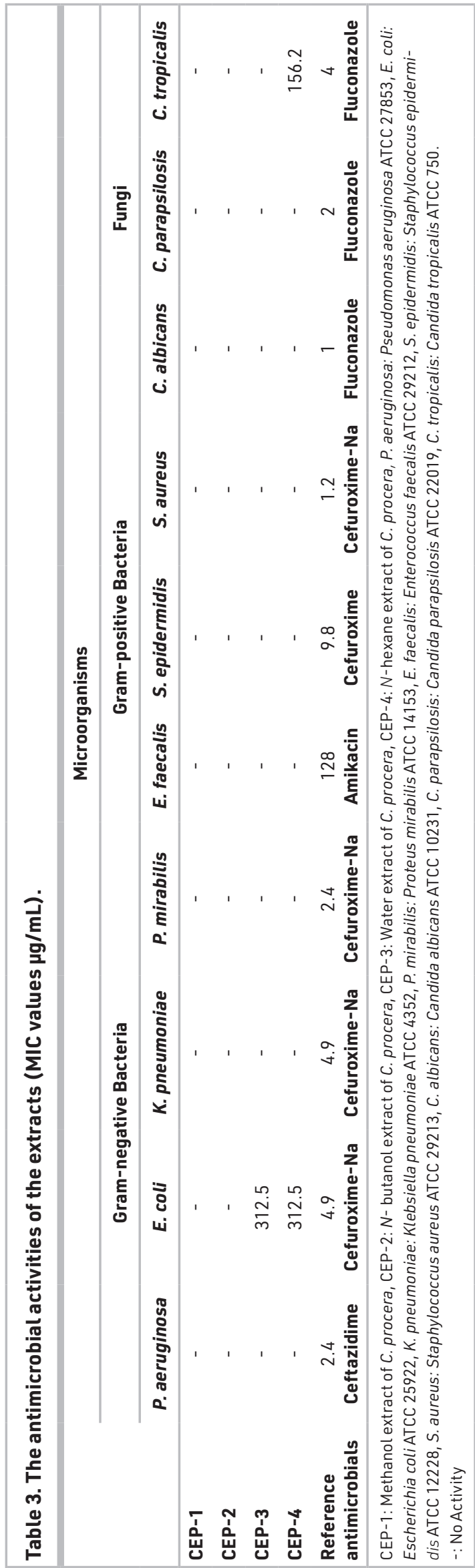
$\mathrm{DNA}+\mathrm{FeSO}_{4}+\mathrm{H}_{2} \mathrm{O}_{2}+(50,100$, and $200 \mu \mathrm{g} / \mathrm{mL}$ of CEP-3). 
ed using agarose gel electrophoresis. The results were presented in Figure 2. Supercoiled pBR322 plasmid DNA in buffer (including \%0.1 DMSO) was used as a negative control and forms I and || was determined as $77.40 \%$ and $22.60 \%$, respectively (Figure 2, lane 1). As shown in Figure 2, when Fenton's reagent was added, supercoiled DNA was damaged (Form I: \%74.80; Form II: \%25.20). When increasing concentrations of CEP-1 and CEP-3 are added into mixture, supercoiled pBR322 plasmid appears to be preserved. Addition of $200 \mu \mathrm{g} / \mathrm{mL}$ of CEP-1 and CEP-3, the amounts of Form I increased from $22.90 \%$ to $43.80 \%$ and $45.60 \%$, respectively (Figure 2, lanes 5 and 8). These results indicated that CEP-1 and CEP-3 protected supercoiled pBR322 plasmid DNA on Fenton's reagents.

\section{Antimicrobial activities of the extracts}

All the in vitro antimicrobial activity results of the tested extracts are given in Table 3. Different concentrations from 1.22 to $2500 \mu \mathrm{g} / \mathrm{mL}$ concentrations of CEP-1 and CEP-2 were tested and none of them showed any activity. However, CEP-3 and CEP-4 exhibited moderate in vitro antibacterial activity against E. coli. Moreover, CEP-4 displayed intense antifungal activity against C. tropicalis. According to antifungal screening results, only CEP-4 was active extract against tested Candida species.

\section{DISCUSSION}

In recent years, natural antioxidants, especially polyphenols, have been notable agents for the treatment of many chronic diseases such as cancer, cardiovascular diseases, diabetes mellitus etc (AlFaris et al., 2021). To the best of our knowledge, there has not been any study conducted to investigate the anti-cholinesterases, anti-tyrosinase, DNA damage, and DNA damage protective activities of C. procera. In this paper, total phenolic contents of the extracts ranged from $79.64 \pm 1.11$ to $13.38 \pm 0.82 \mathrm{mg} \mathrm{GAE} / \mathrm{g}$ dry weight. The results showed that $n$ butanol extract has the highest total phenolic content among the tested extracts. Sarikahya et al. reported that the total phenolic content of $n$-hexane extract was found to be $1.561 \pm 0.042$ mg GAE/g extract (Sarikahya et al. 2015). These results showed that extracts of this study had higher total phenolic contents than Boke Sarikahya's reports. On the other hand, CEP-1 had the best total flavonoid content than other extracts according to the Table 1.

The DPPH assay is a low cost, short time, and simple spectrophotometric method to understand scavenging effects of natural or synthetic compounds (Akar, Küçük \& Doğan, 2017). This assay is based on single electron transfer and hydrogen atom transfer that produces a violet solution (Liang \& Kitts, 2014). In this work, CEP-1 had the best radical scavenging properties following by CEP-3, shown as Table 1. The results of total phenolic/ flavonoid contents and DPPH radical scavenging studies were found to be compatible. Godjevac and co-authors reported the DPPH radical scavenging activity of the flavonoids isolated from the flowers of C. pastricensis (Godjevac et al., 2004). Sarikahya et al. reported that the $n$-hexane extract of DPPH radical scavenging from C. procera determined as $6.938 \pm 2.56 \mathrm{mg} / \mathrm{mL}$ of $\mathrm{IC}_{50}$ value (Sarikahya et al., 2015). According to the literatures, C. procera contains kaempferol, astragalin, tiliroside, quercimer- itrin, gigantoside A, hyperoside, quercitrin, apigenin, luteolin, cynaroside, cyanidin-3-O-glucoside (Sarıkahya \& Kirmizigul, 2012; Sarıkahya, Goren \& Kirmizigul, 2019). These compounds can be responsible for the antioxidant activities of this plant.

Alzheimer's disease (AD), a type of dementia, is the most common form of neurodegenerative disease. Although the pathophysiology of AD has not been clearly established, the cholinergic hypothesis is one of the most accepted causes. According to the cholinergic hypothesis, AD is associated with alterations of cholinergic markers such as cholinesterases (Tuğrak, Gül \& Gülçin, 2020; Kahraman et al., 2019). IC 50 values of the extracts were above $200 \mu \mathrm{g} / \mathrm{mL}$ on AChE for all extracts, while $I C_{50}$ values for BuChE were determined as below $100 \mathrm{\mu g} /$ $\mathrm{mL}$. CEP-3 showed the highest AChE and BuChE inhibitory effects. The results demonstrated that the extracts showed moderate inhibition on BuChE and low inhibition against AChE.

Tyrosinase contains two copper atoms in its active site, and it is a metalloenzyme belonging to the oxidoreductase. It commonly is found in mammals, plants, insects, fungi, and bacteria (Şöhretoğlu, Sari, Barut \& Özel, 2018). Tyrosinase forms melanin pigment from monophenols with many reactions. The excessive formation of melanin pigment causes various problems such as hyperpigmentation, age spots, melanoma etc. (Şöhretoğlu, Sari, Barut \& Özel, 2018). CEP-3 showed more significant tyrosinase inhibitory effects than kojic acid as a positive control $(p<0.001)$ in this study. Studies in the literature show that antioxidant compounds have tyrosinase inhibitory properties (Wang et al., 2018; Morais et al., 2018; Sun, Guo, Zhang \& Zhuang, 2017). In this study, we determined that extracts with a high antioxidant effect showed high tyrosinase inhibition.

The supercoiled DNA damage actions of CEP-1 and CEP-3 were determined by agarose gel electrophoresis. In this paper, CEP1 and CEP-3 extracts were used due to their antioxidant potentials. As presented in Figure 1, the amounts of form I were similar percentages. The results showed that both extracts did not damage supercoiled plasmid DNA at increasing concentrations.

When $\mathrm{FeSO}_{4}$ and $\mathrm{H}_{2} \mathrm{O}_{2}$ are mixed, a hydroxyl radical is formed, and the resulting hydroxyl radical could trigger biological damage such as DNA damage (Barut, Barut, Engin, Özel \& Sezen, 2019). In this work, when Fenton's reagent was added to supercoiled DNA, the amount of form II was determined as $74.80 \%$. On the increasing concentrations of extracts, the amount of form II decreased, and form I increased. The obtained results pointed that both extracts preserved supercoiled pBR322 plasmid DNA against Fenton's reagents.

In antimicrobial activity studies, the antimicrobial potential of the tested extract was examined by MIC method. While CEP-3 and CEP-4 showed antibacterial activity against E. coli, CEP-1 and CEP-2 did not show in vitro activity against all the studied strains. In contrast to our results, Sarıkahya et al. (Böke Sarıkahya, Pekmez, Arda, Kayce, Karabay Yavaşoğlu, \& Kirmizigul, 2011) found strong in vitro antibacterial activity against a panel of bacteria including S. aureus, S. epidermidis, E. coli, E. fae- 
calis, P. aeruginosa and K. pneumoniae with the pure chemical constituents of Cephalaria species in Anatolia. The differences between these results could be explained by using different Cephalaria species and using total or pure contents of the prepared different extracts. On the other hand, although only CEP-4 exhibited excellent antifungal activity against Candida tropicalis, this is the first report on the in vitro antifungal activity of the Cephalaria procera total extracts.

\section{CONCLUSION}

Cephalaria procera is used for wound healing, and as antihemorrhagic in Anatolia, traditionally. This study investigated total phenolic and flavonoid content, DPPH radical scavenging, supercoiled DNA damage/damage protective effects, AChE/BuChE, tyrosinase inhibitory, antimicrobial activities of CEP-1, CEP-2, CEP-3 and CEP-4 obtained from Cephalaria procera. The investigations showed that CEP-1 and CEP-3 had better activities on DPPH radical scavenging, tyrosinase enzyme inhibition, DNA damage/DNA damage protection test systems, while they had higher contents of total phenolic, and flavonoid compared to other extracts. These results suggested that crude methanol and water extracts of C. procera might have a promising potential for the treatment of several disorders associated with skin damage, and further studies are required to confirm these used test systems and mechanisms of action.

Peer-review: Externally peer-reviewed.

Author Contributions: Conception/Design of Study- N.Y.B., B.B., E.M.K., Y.Y.C.; Data Acquisition- N.Y.B., B.B., E.M.K., Y.Y.C.; Data Analysis/ Interpretation- N.Y.B., B.B., E.M.K., Y.Y.C.; Drafting Manuscript- N.Y.B., B.B., E.M.K..; Critical Revision of Manuscript- N.Y.B., B.B., E.M.K., Y.Y.C.; Final Approval and Accountability- N.Y.B., B.B., E.M.K., Y.Y.C.

Conflict of Interest: The authors have no conflict of interest to declare.

Financial Disclosure: Authors declared no financial support.

\section{REFERENCES}

- $\quad$ Akar, Z., Küçük, M., Doğan, H. (2017). A new colorimetric DPPH* scavenging activity method with no need for a spectrophotometer applied on synthetic and natural antioxidants and medicinal herbs. Journal of Enzyme Inhibition and Medicinal Chemistry, 32(1), 643-647. doi: 10.1080/14756366.2017.1284068

- AlFaris, N. A., AlTamimi, J. Z., AlGhamidi, F. A., Albaridi, N. A., Alzaheb, R. A., Aljabryn, D. H., AlMousa, L. A. (2021). Total phenolic content in ripe date fruits (Phoenix dactylifera L.): A systematic review and meta-analysis. Saudi Journal of Biological Sciences. doi: 10.1016/j.sjbs.2021.03.033

- $\quad$ Barut, B., Barut, E. N., Engin, S., Özel, A., Sezen, F. S. (2019). Investigation of the antioxidant, a-glucosidase inhibitory, anti-inflammatory, and DNA protective properties of Vaccinium arctostaphylos L. Turkish Journal of Pharmaceutical Sciences, 16, 175-183. doi: 10.4274/tjps.galenos.2018.28247

- Barut, E. N., Barut, B., Engin, S., Yıldırım, S., Yaşar, A., Turkis, S., Özel, A., Sezen, F. S. (2017). Antioxidant capacity, anti-acetylcholinesterase activity and inhibitory effect on lipid peroxidation in mice brain homogenate of Achillea millefolium. Turkish Journal of Biochemistry, 42, 493-502
Barut, B., Şöhretoğlu, D. (2020). Total phenolic content, cyclooxygenases, a-glucosidase, acetylcholinesterase, tyrosinase inhibitory and DPPH radical scavenging effects of Cornus sanguinea leaves and fruits. Journal of Research in Pharmacy, 24(5), 623-631. doi: 10.35333/jrp.2020.217

- Boke Sarıkahya, N., Goren A.C., Sumer Okkali, G., Kirmizigul, S. (2021). Saponins from twenty-two Cephalaria species. Records of Natural Products, 15(6), 537-546. doi: 10.25135/rnp.241.21.02.1985 Böke Sarıkahya, N., Kirmizigul, S. (2010). Antimicrobial triterpenoid glycosides from Cephalaria scoparia. Journal of Natural Products, 73, 825-830. doi: 10.1021/np900724u

Böke Sarıkahya, N., Pekmez, M., Arda, N., Kayce, P., Karabay Yavaşoğlu, N. Ü., Kırmızıgül, S. (2011). Isolation and characterization of biologically active glycosides from endemic Cephalaria species in Anatolia. Phytochemistry Letters, 4, 415-420. doi: 10.1016/j.phytol.2011.05.006

- Celenk, V. U., Boke Sarikahya, N., Kirmizigul, S. (2020). Isolation and structural studies on saponins from three Cephalaria species from Anatolia. Chemistry of Natural Compounds, 56(1). doi: 10.1007/ s10600-020-02980-w

Chrzaszcz, M., Krzeminska, B., Celinski, R., \& Szewczyk, K. (2021). Phenolic composition and antioxidant activity of plants belonging to the Cephalaria (Caprifoliaceae) genus. Plants, 10, 952. doi: 10.3390/plants10050952

- Clinical and Laboratory Standards Institute. (2020). Performance standards for antimicrobial susceptibility testing,30th Edition in, Clinical and Laboratory Standards Institute; M100. Wayne, PA, USA.

- Clinical and Laboratory Standards Institute. (1997). Reference method for broth dilution antifungal susceptibility testing of yeasts; Approved standard-Second Edition; M27-A2. Wayne, PA, USA.

- Faydaoğlu, E., \& Sürücüoğlu, M. S. (2011). Geçmişten günümüze tıbbi ve aromatik bitkilerin kullanılması ve ekonomik önemi (The use and economic importance of medicinal and aromatic plants from past to present). Journal of Forestry Faculty, 11 (1), 52-57.

Godjevac, D., Vajs, V., Menkovic, N., Tesevic, V., Janackovic, P., Milosavijevic, S. (2004). Flavonoids from flowers of Cephalaria pastricensis and their antiradical activity. Journal of the Serbian Chemical Society, 69(11) 883-886.

- Göktürk, R. S. \& Sümbül, H. (2014). A taxonomic revision of the genus Cephalaria (Caprifoliaceae) in Turkey, Turkish Journal of Botany, 38, 927-968. doi: 10.3906/bot-1310-6.

- Kahraman, C., Baysal, I., Çankaya, I., Goger, F., Kirimer, N., \& Akdemir, Z. S. (2019). Acetylcholinesterase inhibitory activities and LC-MS analysis of the antioxidant Ferula caspica M. Bieb. and F. halophila Pesmen extracts. doi: 10.12991/jrp.2019.161

Morais, D. V. D., Costa, M. A. P. D. C., Santa Bárbara, M. F., Silva, F. D. L., Moreira, M. M., Delerue-Mato, C., Carvalho, C. A. L. D. (2018). Antioxidant, photoprotective and inhibitory activity of tyrosinase in extracts of Dalbergia ecastaphyllum. PloS one, 13(11), e0207510. doi: 10.1371/journal.pone.0207510

Mustafayeva, K., Mahiou-Leddet, V., Suleymanow, T., Kerimov, Y., Ollivier, E., Elias, R. (2011). Chemical constituents from the roots of Cephalaria kotschyi. Chemistry of Natural Compounds, 47(5).

- Newman, D. J., \& Cragg, G. M. (2020). Natural products as sources of new drugs over the nearly four decades from 01/1981 to 09/2019. Journal of Natural Products, 83(3).

- $\quad$ Özgen, U., Kaya, Y., Houghton, P. (2012). Folk Medicine in the villages of Ilıca District (Erzurum, Turkey). Turkish Journal of Biology, 36; 93-106. doi: 10.3906/biy-1009-124

- Pasi, S., Aligiannis, N., Skaltsounis, A. L., Chinou, I. B. (2002). A new lignan glycoside and other constituents from Cephalaria ambrosioides. Natural Product Letters, 16(6), 365-370. doi: 10.1080/10575630290030720 
- $\quad$ Sarikahya, N.B., Goren, A.C., \& Kirmizigul, S. (2019). Simultaneous determination of several flavonoids and phenolic compounds in nineteen different Cephalaria species by HPLC-MS/MS. Journal of pharmaceutical and biomedical analysis, 173, 120-125. doi: 10.1016/j.jpba.2019.05.019.

- Sarikahya, N.B., Ucar, E.O., Kayce, P., Gokturk, R.S., Sumbul, H., Arda, N., Kirmizigul, S. (2015). Fatty acid composition and antioxidant potential of ten Cephalaria species. Records of Natural Products, 9, 116-123.

- Sarıkahya, N.B., \& Kirmizigul, S. (2012). Antimicrobially active hederagenin glycosides from Cephalaria elmaliensis. Planta medica, 78(08), 828-833. doi: 10.1055/s-0031-1298415.

- Sun, L., Guo, Y., Zhang, Y., \& Zhuang, Y. (2017) Antioxidant and anti-tyrosinase activities of phenolic extracts from rape bee pollen and inhibitory melanogenesis by CAMP/MITF/TYR pathway in B16 mouse melanoma cells. Frontiers in Pharmacology, 8(104). doi: 10.3389/fphar.2017.00104

- S S Söhretoğlu, D., Barut, B., Sari, S., Özel, A., Arroo, R. (2020). In vitro and in silico assessment of DNA interaction, topoisomerase I and II inhibition properties of chrysosplenetin. International Journal of Biological Macromolecules, 163, 1053-1059. doi: 10.1016/j. ijbiomac.2020.07.049
- S Şöhretoğlu, D., Sari, S., Barut, B., \& Özel, A. (2018). Tyrosinase inhibition by some flavonoids: Inhibitory activity, mechanism by in vitro and in silico studies. Bioorganic chemistry, 81, 168-174. doi: 10.1016/j.bioorg.2018.08.020.

- Top, H., Boke Sarikahya, N., Nalbantsoy, A., Kirmizigul, S. (2017). Immunomodulatory, hemolytic properties and cytotoxic activity potent of triterpenoid saponins from Cephalaria balansae. Phytochemistry, 137, 139-147.

- Tuğrak, M., Gül, H. I., \& Gülçin, I. (2020). Acetylcholinesterase inhibitory potencies of new pyrazoline derivatives. Journal of Research in Pharmacy, 24(4), 464-471. doi: 10.35333/jrp.2020.194

- Wang, Y., Hao, M. M., Sun, Y., Wang, L. F., Wang, H., Zhang, Y. J., Li H. Y, Zhuang PW \& Yang, Z. (2018). Synergistic promotion on tyrosinase inhibition by antioxidants. Molecules, 23(1), 106. doi: 10.3390/molecules230101060 